\title{
The availability to pigs of nicotinic acid in tortilla baked from maize treated with lime-water
}

\author{
By E. KODICEK \\ Dunn Nutritional Laboratory, University of Cambridge and Medical Research Council \\ AND R. BRAUDE, S. K. KON AND K. G. MITCHELL \\ National Institute for Research in Dairying, Shinfield, Reading
}

(Received 7 April 1959)

\begin{abstract}
Almost two decades ago Kodicek (1940 $a, b)$ observed that nicotinic acid in maize and other cereals is in a bound form that is rendered free only by hydrolysis with alkali; he postulated that only a small fraction of the total amount of nicotinic acid in maize is 'active' and able to prevent or cure pellagra. Subsequent experiments on dogs with the black-tongue syndrome confirmed the hypothesis and showed that the biological potency of yellow-maize flour, containing $12-27 \mu \mathrm{g}$ nicotinic acid/g by chemical assay, was in fact equivalent to less than $7 \mu \mathrm{g} / \mathrm{g}$ (Kodicek, 1940 $b, \mathrm{r942}$ ). The existence of such a bound form of nicotinic acid in cereals was confirmed by a number of workers (for references see Kodicek, I95 I $a$; Kodicek, Braude, Kon \& Mitchell, r956). The bound nicotinic acid proved to be unavailable or only partly available to Lactobacillus arabinosus and Lb. casei (Krehl \& Strong, r944; Kodicek \& Pepper, r948; Clegg, Kodicek \& Mistry, I952), to the rat (Chaudhuri \& Kodicek, 1950; Kodicek, I95 I $b$; Harper, Punekar \& Elvehjem, I958) and to poultry (Krehl, Elvehjem \& Strong, 1944; Coates, Ford, Harrison, Kon, Shepheard \& Wilby, I952; Heuser \& Scott, 1953). More recently it was shown that the pig cannot utilize the bound nicotinic acid in maize (Kodicek et al. 1956).
\end{abstract}

Hydrolysis with dilute $\mathrm{NaOH}$ liberated the nicotinic acid in maize which then cured the nicotinic-acid deficiency produced by a maize diet in rats (Chaudhuri \& Kodicek, I950; Kodicek, I95 $b$; Harper et al. 1958), in dogs and chicks (McDaniel \& Hundley, I958) and in pigs (Kodicek et al. 1956). Another alkali treatment, namely cooking with $\mathrm{r} \%$ lime-water and subsequent baking of the mash, is used for making tortilla, a staple food in Mexico. Tortilla proved to have the same curative effect on deficient rats (Laguna \& Carpenter, I95I ; Cravioto, Massieu, Cravioto \& Figueroa, I952; Squibb, Braham, Arroyave \& Scrimshaw, I955; Massieu, Cravioto, Cravioto, Guzmán \& Suarez Soto, 1956; Fiorentini, Gaddi \& Bonomolo, 1956; Pearson, Stempfel, Valenzuela, Utley \& Darby, I957). However, Krehl, Henderson, de la Huerga \& Elvehjem (1946) used tortilla as one of the foods tested in their original demonstration of relationship between the metabolism of nicotinic acid and tryptophan in rats and found it ineffective as a source of nicotinic acid, and Goldsmith, Gibbens, Unglaub $\&$ Miller (1956) were unable to detect with maize treated with lime-water a preventive effect on human pellagra. The negative results of the latter workers, as they themselves pointed out, may have been due partly to the fact that only $15-20 \%$ of the 
calories were furnished by the maize, so that the amount of nicotinic acid derived from it, even after hydrolysis, would have been insufficient to effect a cure. Kodicek \& Wilson (1959) have suggested that some of the discrepancies between the findings of different workers may be explained by the extent to which nicotinic acid was liberated, and the conditions of the lime-water treatment.

The curative effects of maize treated with lime-water observed by most workers may be ascribed to the liberation of bound nicotinic acid, as affirmed by Laguna \& Carpenter (195I) and more recently by Harper et al. (1958). Cravioto, Massieu et al. (1952) originally suggested that, in view of apparent losses in the amino-acid content of tortilla, the beneficial effect of alkali treatment results from the correction of the imbalance of amino acids observed by Massieu, Guzmán, Cravioto \& Calvo (r949). However, on re-investigation, Massieu et al. (1956) as well as Pearson et al. (r957) detected no effect of alkali treatment on the proportions of essential amino acids and adopted the view suggested by Kodicek (1940 $a, b$ ) that the explanation of the curative phenomenon lies in the liberation of bound nicotinic acid. Bressani \& Scrimshaw (1958) likewise did not find the differences between the amino acids of maize and tortilla great enough to provide an explanation for the biological differences between maize and tortilla revealed by experiments with animals. In spite of their findings, Bressani \& Scrimshaw concurred with the view expressed by Squibb et al. (1955) and Goldsmith (1956) that correction of an imbalance of amino acids by alkali hydrolysis is the explanation. They suggested that the decreased solubility of zein in $75 \%$ alcohol after lime-water treatment may be reflected in a decreased digestibility of that ill-balanced protein and hence a 'decreased availability of the amino acids from the poorest of the corn proteins could in turn have the effect of improving the biological value of those actually released from maize by enzyme action'. However, in an experiment specifically designed to determine whether the availability of the amino acids of maize was affected by alkali treatment, Harper et al. (1958) found no change in the availability of essential amino acids and concluded that the curative effect could be entirely explained by the liberation of bound nicotinic acid.

All the experiments just discussed were made on rats, and we thought it of importance to reproduce the effects in pigs, whose nicotinic-acid metabolism resembles that of man more closely than does that of the rat. The experiment with pigs to be described was essentially similar in design to that done by us previously (Kodicek et al. 1956), but tortilla baked from maize treated with lime-water was used instead of maize treated with $\mathrm{NaOH}$. In addition, the liberation of bound nicotinic acid was followed by chemical, microbiological and chromatographic tests.

\section{EXPERIMENTAL}

Estimation of nicotinic acid in dietary constituents. Total nicotinic acid was estimated chemically by a modification of the method of Wang \& Kodicek (1943) and microbiologically with $L b$. casei ATCC 7469 (Clegg et al. 1952). Bound nicotinic acid was estimated by the difference in response of $L b$. casei to hydrolysed and unhydrolysed extracts, as described previously (Kodicek et al. 1956). 
The results of these analyses are shown in Table $I$. It can be seen that maize had most of its nicotinic acid in bound form, whereas tortilla, pea meal and casein contained nicotinic acid in available, free form. Paper chromatography (Fig. $x$ ) showed conclusively that the nicotinic acid in maize exists in bound form, but that tortilla has its nicotinic acid in free form, which moves at the same $R_{F}$ as nicotinic acid added to the extract. The small amount of the vitamin available in maize was derived from the germ (see Kodicek, I95 I $a$ ), which contains $1.7 \%$ of the total nicotinic acid (Heathcote, Hinton \& Shaw, 1952); the vitamin appeared in the chromatogram in traces in the regions of free nicotinic acid and free nicotinamide.

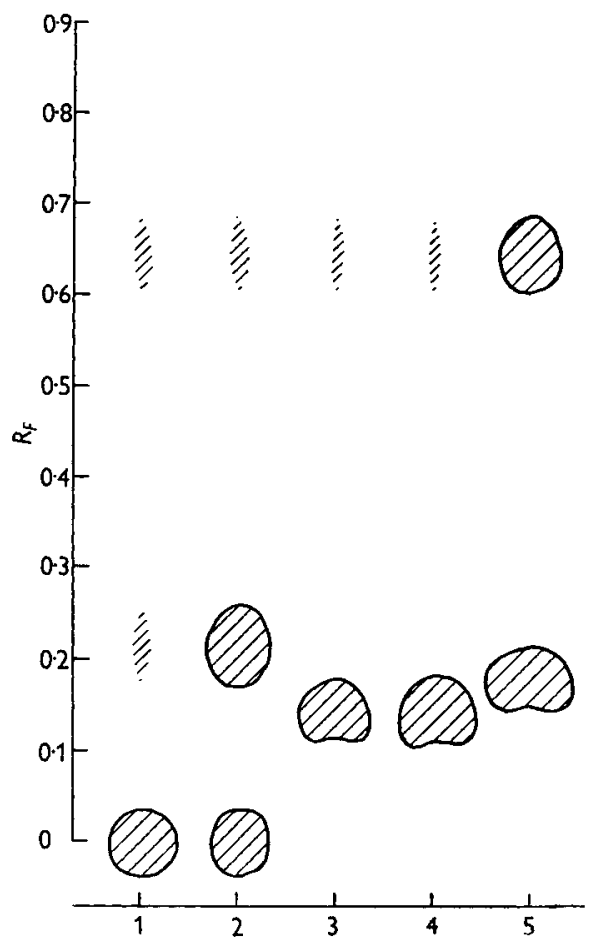

Fig. 1. Paper chromatogram of extracts of maize and tortilla prepared as described by Kodicek et al. (1956). Solvent: n-butanol-water; ascending flow for $20 \mathrm{~h}$ on Whatman no. I. Spots: $40 \mu \mathrm{l}$, detected by $\mathrm{CNBr}$-p-aminobenzoic-acid reaction as yellow-coloured, fluorescent spots. 1, maize extract; 2 , maize extract with I $\mu \mathrm{g}$ nicotinic acid; 3 , tortilla extract; 4 , tortilla extract with I $\mu \mathrm{g}$ nicotinic acid; 5 , nicotinic acid and amide, $2 \mu \mathrm{g}$ each.

Estimation of other vitamins and tryptophan in dietary constituents. Tryptophan was estimated chemically by the method of Graham, Smith, Hier \& Klein (1947). Thiamine estimations were made by the thiochrome method of Harris \& Wang (194I) and microbiologically by our colleague, Dr Margaret Gregory, with Lactobacillus fermenti $\mathrm{P}_{3} 6$ (Sarett \& Cheldelin, I944). The results in Table 2 are the mean of both estimations. Riboflavin was estimated chemically (Kodicek \& Wang, I949) and microbiologically with $L b$. casei ATCC 7469 by the method of Clegg et al. (1952), and by Dr Gregory by the method of Skeggs, Nepple, Valentik, Huff \& 
Wright (1950). All these techniques gave similar results, and the mean values are shown in Table 2. Dr Gregory estimated also pantothenic acid by the method of Chapman, Ford, Kon, Thompson, Rowland, Crossley \& Rothwell (1957) with the enzyme-digestion technique of Neilands \& Strong (1948), total vitamin $B_{6}$ activity by the method of Chapman et al. (1957), folic and folinic acids, respectively, by the method of Teply \& Elvehjem (1945) with Streptococcus faecalis, and by the method of Sauberlich \& Baumann (1948) with Pediococcus cerevisiae ATCC 8081. For the last

Table I. Nicotinic-acid content of constituents of diets $(\mu g / g)$

\begin{tabular}{|c|c|c|c|c|c|c|}
\hline \multirow[b]{2}{*}{$\begin{array}{c}\text { Con- } \\
\text { stituent }\end{array}$} & \multirow{2}{*}{$\begin{array}{l}\text { Unhydrolysed } \\
\text { extract. } \\
\text { Micro- } \\
\text { biological } \\
\text { test }\end{array}$} & \multicolumn{3}{|c|}{ Hydrolysed extract (total nicotinic acid) } & \multicolumn{2}{|c|}{ Original product } \\
\hline & & $\begin{array}{c}\text { Microbiological } \\
\text { test }\end{array}$ & $\begin{array}{l}\text { Chemical } \\
\text { test }\end{array}$ & $\begin{array}{l}\text { Mean } \\
(a)\end{array}$ & $\begin{array}{c}\text { Free* } \\
\quad(b)\end{array}$ & $\begin{array}{l}\text { Bound } \\
(a-b)\end{array}$ \\
\hline Maize & $8 \cdot I \dagger$ & $17 \cdot 2$ & I $8 \cdot 7$ & I $8 \cdot 0$ & $0 \cdot 3$ & $x 7 \cdot 7$ \\
\hline Tortilla & $10 \cdot 8$ & 10.4 & $1 \mathrm{I} \cdot 7$ & II $\cdot 0$ & II ${ }^{\circ}$ & $\circ$ \\
\hline Pea meal & $17 \cdot 6$ & $16 \cdot 9$ & $13 \cdot 1$ & $15 \cdot 9$ & $15 \cdot 9$ & $\circ$ \\
\hline Casein & 一 & $I \cdot 5$ & - & $\mathrm{I} \cdot 5$ & $\mathrm{I} \cdot 5$ & $\circ$ \\
\hline
\end{tabular}

* In maize free nicotinic acid or the amide is present (cf. Fig. I) only in the germ (Kodicek, $195 \mathrm{I} a$ ). The value for maize was obtained by paper chromatography (cf. Kodicek et al. 1956), which showed also that in tortilla and pea meal only the free form is present. In casein the traces of nicotinic acid are in the free form (Kodicek \& Pepper, 1948).

+ Some $30-50 \%$ of the bound nicotinic acid in maize is available to $L b$. casei under the conditions of the microbiological test (Clegg et al. 1952).

Table 2. Vitamin and tryptophan content of constituents of the diets

\begin{tabular}{|c|c|c|c|c|}
\hline & Maize & Tortilla & Pea meal & Casein \\
\hline Tryptophan (mg/g) & 0.85 & 0.85 & $2 \cdot 5$ & 10.4 \\
\hline Thiamine $(\mu \mathrm{g} / \mathrm{g})$ & $4 \cdot 6$ & 0.39 & $7 \cdot 2$ & 0.10 \\
\hline Riboflavin $(\mu \mathrm{g} / \mathrm{g})$ & 0.43 & 0.27 & $I \cdot I$ & 0.09 \\
\hline $\begin{array}{l}\text { Calcium pantothenate } \\
(\mu \mathrm{g} / \mathrm{g})\end{array}$ & $3 \cdot 4$ & $I \cdot I$ & $8 \cdot 9$ & 0.08 \\
\hline Vitamin $\mathrm{B}_{6} *(\mu \mathrm{g} / \mathrm{g})$ & $3 \cdot 4$ & $1 \cdot 7$ & $1 \cdot 2$ & 0.19 \\
\hline Folic acid $(\mathrm{m} \mu \mathrm{g} / \mathrm{g})$ & 70 & 8 & 270 & $<0.5$ \\
\hline Folinic acid $(\mathrm{m} \mu \mathrm{g} / \mathrm{g})$ & - & - & 140 & $<0.5$ \\
\hline Biotin $(\mathrm{m} \mu \mathrm{g} / \mathrm{g})$ & 20 & 20 & 23 & 6 \\
\hline Vitamin $B_{12}(m \mu g / g)$ & $<0.1$ & $\ldots$ & 0.04 & $6 \cdot 7$ \\
\hline Tocopherols $\nmid(\mu \mathrm{g} / \mathrm{g})$ & $16 \cdot 0$ & $4 \cdot 6$ & $13 \cdot 2$ & 0 \\
\hline
\end{tabular}

* Expressed as pyridoxine hydrochloride.

$\dagger$ Expressed as $\alpha$-tocopherol (see Table 3 ). In the diets tocopherols were also supplied by cod-liver oil. Its $\alpha$-tocopherol content was taken to be ro $\mathrm{mg} / \mathrm{ro0}$ g (Moore, Sharman \& Ward, I959).

two assays the enzyme method of Sreenivasan, Harper \& Elvehjem (I949) was adopted. She estimated also biotin by the method of Chapman et al. (I957) and vitamin $B_{12}$ with Lactobacillus leichmannii ATCC 4797 after extraction from the samples by steaming with cyanide in sodium-acetate buffer at $\mathrm{pH} 4 \cdot 6$ (Gregory, 1954). Samples were also treated with alkali, and the alkali blank was subtracted from the result to give the true vitamin $\mathrm{B}_{12}$ content.

Since it was suspected that in the previous experiment (Kodicek et al. 1956) some of the pigs might have suffered from a vitamin E deficiency, caused by destruction of tocopherols during the alkali treatment, the tocopherol content of the dietary constituents was determined by our colleague, Dr R. J. Ward, using the paper-chromato- 
Vol. I3

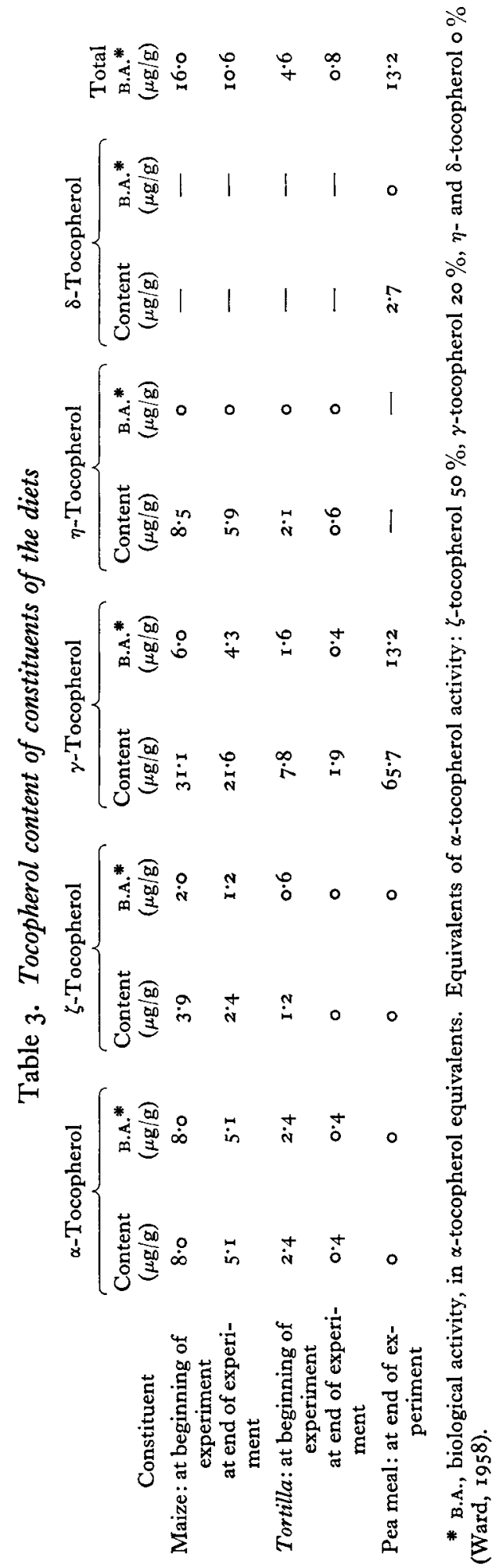


graphic procedure of Green, Marcinkiewicz \& Watt (1955). Table 3 shows the tocopherol contents of maize tortilla and pea meal and the total $\alpha$-tocopherol equivalents. Casein did not contain any tocopherol. The concentration of $\alpha$-tocopherol in codliver oil was taken to be $10 \mathrm{mg} / 100 \mathrm{ml}$ (Moore et al. 1959). It can be seen that the treatment with lime-water greatly reduced the tocopherol content and that there was loss of tocopherol during storage of the samples while the experiment was in progress, particularly from the alkaline tortilla. This result fully justified the supplementation of the diet with $\alpha$-tocopheryl acetate, as will be mentioned later. Dr Ward estimated the tocopherol content also of pig serum by the procedure of Quaife \& Harris (1944).

Animals and diets. Eighteen weanling Large White pigs (nine of each sex) from four litters, weighing $42-56 \mathrm{lb}$ were assigned at the beginning of the preliminary period to one of three groups: group I deficient controls (nos. 2, 6, I I, 15, 19, 2I), group 2 given a supplement of nicotinic acid (nos. 4, 8, 10, 14, I8, 24) and group 3 given dried, ground tortilla (nos. I, 5, 12, I3, 17, 22). Litter-mates were assigned to the treatments at random. The management and housing of the pigs were as previously described (Kodicek et al. 1956).

\section{Table 4. Percentage composition of diets used in the preliminary period and in the experiment proper}

\begin{tabular}{lcc}
\multicolumn{1}{c}{ Constituent } & Diet I* & Diet 2* \\
Maize, white, ground & 79.0 & - \\
Tortilla, dried, ground & - & 79.0 \\
Pea meal & 10.5 & 10.5 \\
Casein & $5 \cdot 0$ & 5.0 \\
Cod-liver oil & 3.0 & 3.0 \\
Minerals $\dagger$ & $2 \cdot 0$ & $2 \cdot 0$ \\
NaCl & 0.5 & 0.5 \\
Vitamins & $\ddagger$ & $\ddagger$
\end{tabular}

Each pig was dosed weekly with $350 \mathrm{mg} \alpha$-tocopheryl acetate dissolved in $2 \mathrm{ml}$ arachis oil.

* Diet 1 , diet for all groups in the preliminary period, and for group I (negative control) and group 2 given supplements of nicotinic acid in the experiment proper; diet 2, diet for group 3 given tortilla in the experiment proper.

$\uparrow$ Calcium carbonate 200 , bone ash 200 , ferric oxide 8 , parts by weight.

I In $\mathrm{mg} / \mathrm{100} \mathrm{lb}$ diet: thiamine hydrochloride 72 , riboflavin 108 , calcium pantothenate 720 , pyridoxine hydrochloride 104, cyanocobalamin $0 \cdot 52$, folic acid $2 \cdot 8$, biotin (free acid) $0 \cdot 8$.

The experiment was divided into two periods. In the preliminary period all the pigs received the maize diet deficient in nicotinic acid shown in Table 4 (diet $\mathrm{I}$ ). The diet was essentially that used in the previous experiment (Kodicek et al. 1956), except that adequate vitamin supplements were included to prevent any concurrent vitamin deficiencies. Each pig was dosed once weekly with $35^{\circ} \mathrm{mg} \alpha$-tocopheryl acetate dissolved in $2 \mathrm{ml}$ arachis oil.

All pigs were weighed twice weekly. Each was placed individually on the experiment proper, when it had ceased to gain or had lost weight for 7 days. This arbitrary criterion of depletion was the same as in the previous experiment. The pigs in groups I and 2 continued on diet $\mathrm{I}$, those in group $\mathrm{I}$ serving as deficient controls, whereas each of those in group 2 received by mouth a daily supplement of $6 \mathrm{mg}$ nicotinic acid 
dissolved in $2 \mathrm{ml}$ water. Group 3 was given diet 2 (Table 4 ), which differed from diet $\mathrm{I}$ in that the maize was replaced by ground tortilla (see below). The animals were maintained on the same diets for IO-I2 weeks or until they succumbed to deficiency.

Preparation of tortilla. The tortilla was made as described by Cravioto, Anderson, Lockhart, Miranda \& Harris (I945). Tortilla from about $\mathrm{I}$ ton of maize was needed for the experiment. The Directors of Huntley and Palmers Ltd, Reading, kindly agreed to prepare it for us at their factory. Of a consignment of 4 tons of white maize, I ton was sent to them for treatment, and the remaining 3 tons were used for preparation of the other diets to be used in the experiment. The factory processed the maize in six batches by the procedure outlined in Table 5 and supplied us with about 16 cwt of dried ground tortilla.

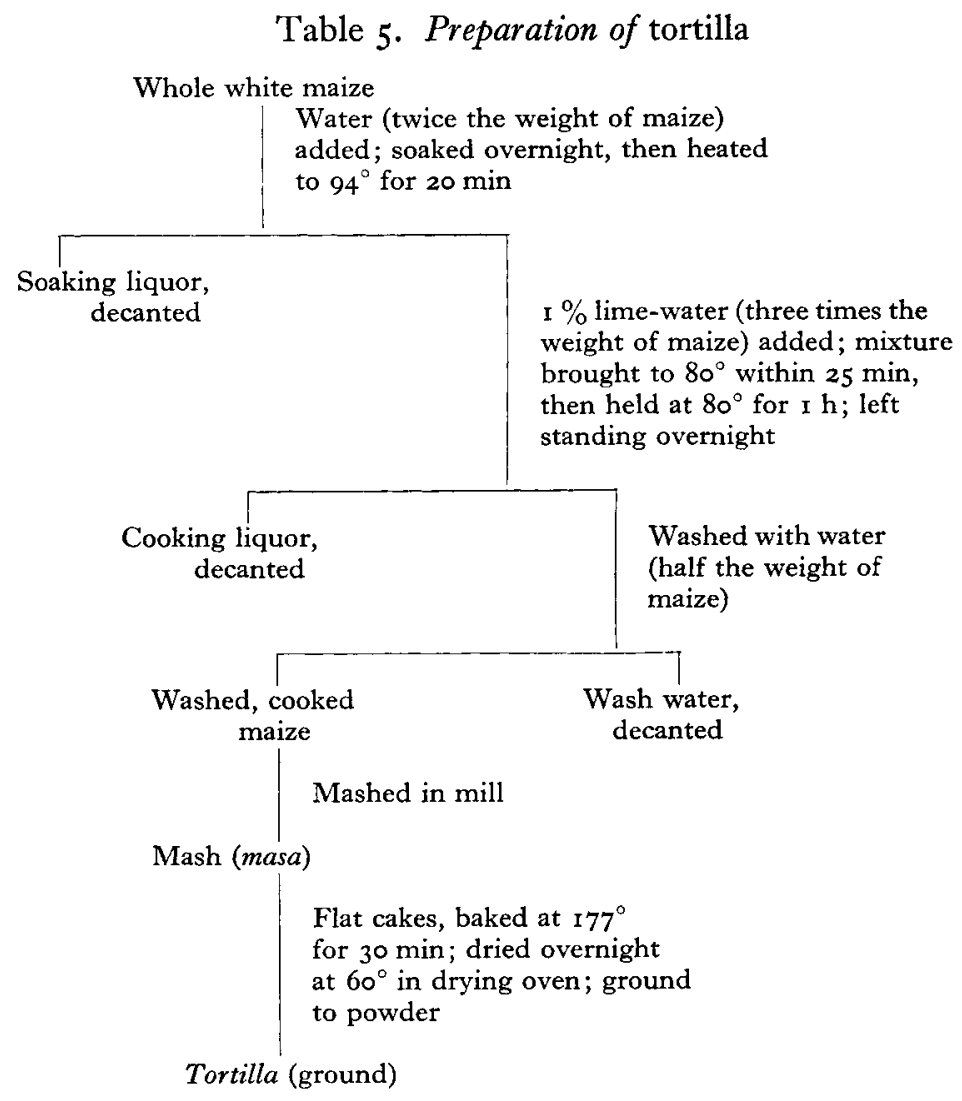

In preliminary trials tortilla was made on the laboratory scale from Plate Argentinian yellow maize. Results of chemical analysis of the intermediate products are shown in Table 6. It will be seen that more than half of the nicotinic-acid content was lost in the liquors, but there did not seem to be any loss from destruction during the baking of tortilla from the mash (masa). The total losses of thiamine and riboflavin were considerable, 85.9 and $68.1 \%$ respectively. They were due partly to extraction into the liquors, but mainly to destruction. The findings agree well with those reported by Cravioto, Figueroa, Cravioto \& Massieu (1952), Paz y Paz (1953), 
Pellett \& Platt (1956) and Bressani, Paz y Paz \& Scrimshaw (1958). Vitamin losses will depend on the condition of treatment, i.e. amount of washing, degree of alkalinity and extent of baking. In comparison with maize the finished tortilla was low in thiamine and riboflavin and, to a less extent, in total nicotinic acid. The nicotinic acid was, however, in the free form.

In the large-scale preparation of tortilla, similar losses of the same vitamins were encountered (Tables $\mathbf{r}$ and $\mathbf{2}$ ). Table $\mathbf{2}$ shows, in addition, large losses of pantothenic acid, total vitamin $B_{6}$ activity and folic acid. The tocopherol content also was greatly reduced (Table 3 ).

Table 6. Nicotinic acid, thiamine and riboflavin content of intermediate products in the preparation of tortilla in preliminary trials with small batches of Plate Argentinian yellow maize

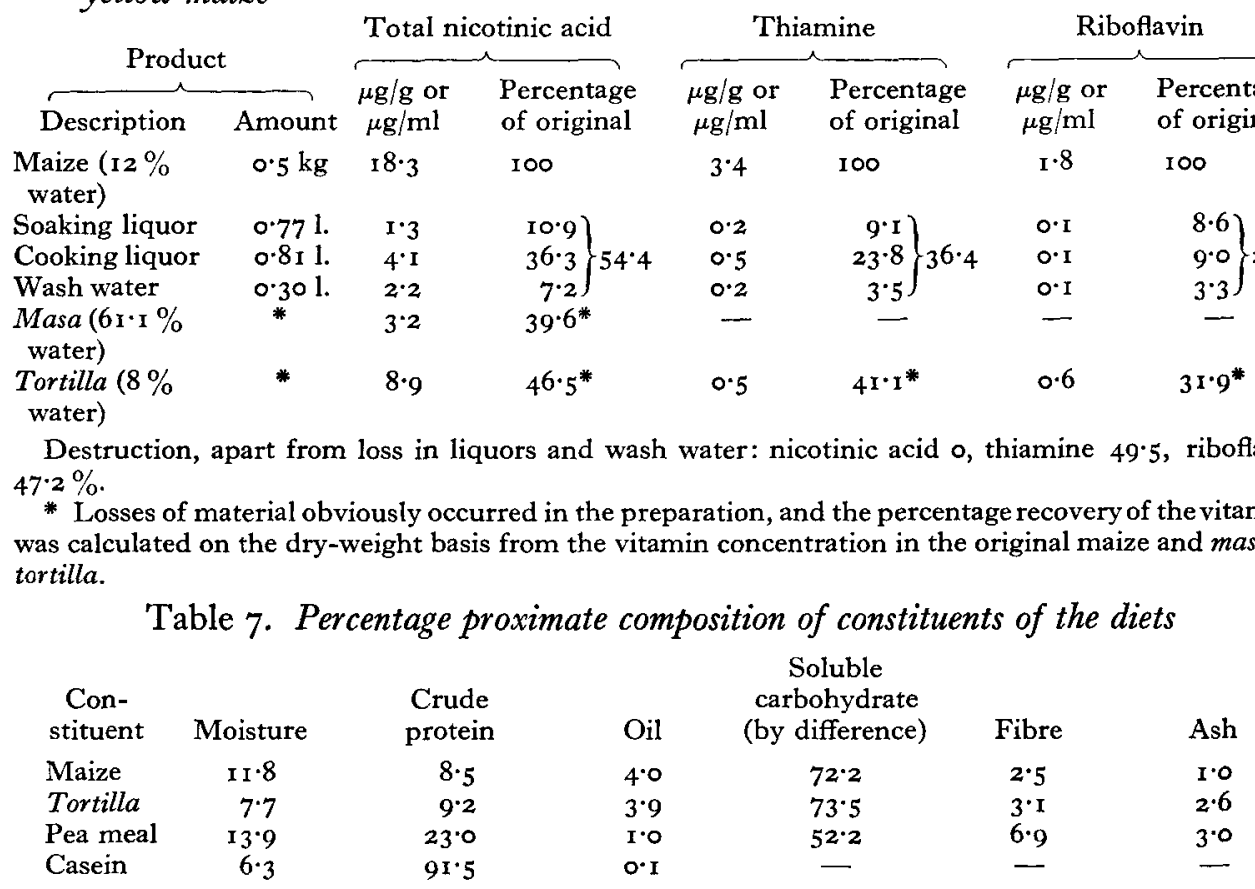

The percentage of crude protein, oil, soluble carbohydrate, fibre and ash in the constituents of the diet are shown in Table 7. No marked differences between maize and tortilla are apparent.

Nutrient content of diets. Table 8 shows the protein, carbohydrate, vitamin and tryptophan contents of diets I and 2. Diet I, given to all groups in the preliminary period and to groups $I$ and 2 in the experiment proper, had $7.24 \mathrm{mg}$ nicotinic acid/lb, $88 \%$ of which was in the bound form. The remainder was free nicotinic acid derived from pea meal $(0.76 \mathrm{mg} / \mathrm{lb})$, maize germ ( $0.1 \mathrm{I} \mathrm{mg} / \mathrm{lb})$ and casein $(0.03 \mathrm{mg} / \mathrm{lb})$. Diet 2 given to group 3 had $4.73 \mathrm{mg}$ nicotinic acid/lb, all in the free form owing to the substitution of tortilla for maize. The deficiencies of the other vitamins were corrected by supplements (see Table 4 ). 
Table 8. Nutrient content of the diets, including vitamin supplements

\begin{tabular}{|c|c|c|}
\hline Nutrient & Diet $I^{*}$ & Diet $2^{*}$ \\
\hline Protein $(\mathrm{g} / \mathrm{lb})$ & $62 \cdot 2$ & $64 \cdot 6$ \\
\hline Carbohydrate $(\mathrm{g} / \mathrm{lb})$ & 283.7 & $288 \cdot 4$ \\
\hline $\begin{array}{l}\text { Nicotinic acid: } \\
\text { Free }(\mathrm{mg} / \mathrm{lb}) \\
\text { Bound }(\mathrm{mg} / \mathrm{lb}) \\
\text { Total }(\mathrm{mg} / \mathrm{lb})\end{array}$ & $\begin{array}{l}0.90 \\
6 \cdot 34 \\
7 \cdot 24\end{array}$ & $\begin{array}{l}4 \cdot 73 \\
0 \\
4 \cdot 73\end{array}$ \\
\hline Tryptophan (mg/lb) & $659 \cdot 6$ & $659^{\circ} 6$ \\
\hline Thiamine (mg/lb) & $2 \cdot 71$ & $1 \cdot 20$ \\
\hline Riboflavin (mg/lb) & $1 \cdot 29$ & $1 \cdot 23$ \\
\hline Calcium pantothenate $(\mathrm{mg} / \mathrm{lb})$ & $8 \cdot 84$ & 8.02 \\
\hline Vitamin $\mathrm{B}_{8} \dagger(\mathrm{mg} / \mathrm{lb})$ & $2 \cdot 32$ & $1 \cdot 71$ \\
\hline Tocopherols $\ddagger$ (mg/lb) & $7 \cdot 72$ & 3.57 \\
\hline Folic acid $(\mu \mathrm{g} / \mathrm{lb})$ & $72 \cdot 1$ & $49 \cdot 9$ \\
\hline Biotin $(\mu \mathrm{g} / \mathrm{lb})$ & $16 \cdot 40$ & $16 \cdot 40$ \\
\hline Vitamin $B_{12}(\mu \mathrm{g} / \mathrm{lb})$ & $5 \cdot 35$ & $5 \cdot 35$ \\
\hline
\end{tabular}

* Diet I, pellagra-producing diet; diet 2, tortilla diet.

† Expressed as pyridoxine hydrochloride.

$\mp$ Expressed as $\alpha$-tocopherol (see Table 3 ). The tocopherol of the diets was derived from maize or tortilla, pea meal and cod-liver oil (see Table 2). The diets were supplemented by dosing each pig with $350 \mathrm{mg} \alpha$-tocopheryl acetate weekly.

\section{RESULTS}

The individual growth curves of the pigs, their food consumption and intake of nicotinic acid, bound or free, and of tryptophan are shown in Fig. 2, and mean values are plotted in Fig. 3.

\section{Preliminary period}

Tables 9-II show the average performance of the pigs and their intake of food constituents. The mean initial weight was similar for all three groups. The mean length of the preliminary period varied considerably between the groups. The pigs in group $\mathbf{r}$ happened to become deficient in the shortest time, within 26-40 days; four pigs in group 2 became deficient within $2 \mathrm{I}-45$ days, but pigs nos. 14 and 18 took 77 and 66 days, respectively, to reach a plateau. In group 3 , four pigs took $3 \mathrm{I}-48$ days to become deficient, as judged by weight performance, but pigs nos. I and 5 did not begin to lose weight until the 66th and 7oth day and died before they could be placed on the experiment proper. As in the previous experiment (Kodicek et al. 1956), most pigs scoured in the later stages of depletion. The economy of food utilization became uniformly worse, the mean value being $5 \cdot 0-5 \cdot 2 \mathrm{lb}$ food consumed for $\mathrm{x} l \mathrm{~b}$ weight gain. The mean intake of free nicotinic acid was only $2 \cdot 2-2 \cdot 6 \mathrm{mg} / \mathrm{day}$, but the intake of total nicotinic acid ranged on average from 17.4 to $21 \mathrm{mg} /$ day and, although the pigs obtained daily from the diet $\mathrm{I} \cdot 6-\mathrm{I} \cdot 9 \mathrm{~g}$ tryptophan, they became deficient. On the other hand, owing to the generous supplementation, the intake of vitamins other than nicotinic acid was well above the recommended allowances (Table II). 


\section{Experiment proper}

The results were clear-cut (Tables 9-I I, Figs. 2 and 3 ).

The deficient control pigs (group I) gained little weight at the beginning and all lost considerably in the last 2-4 weeks of the experiment. Two pigs (nos, 6 and $2 \mathrm{I}$ ) died on the 2 rst and 28 th day, respectively. The mean gain in weight was only $\mathrm{I} \cdot 7 \mathrm{lb}$ per week, with a low food intake of $2.9 \mathrm{lb} /$ day and a bad utilization of food, $\mathrm{II} .9 \mathrm{lb}$ food/lb gain. The consumption of free and bound nicotinic acid and of tryptophan was much the same as in the preliminary period.

In group 2, given $6 \mathrm{mg}$ nicotinic acid daily, pig no. 18 which had become severely deficient in the preliminary period died on the 8th day. Values for it are not included among the results of the experiment proper. The remaining five pigs recovered from the deficiency, ceased scouring and gained steadily in weight, with an average gain of $6.5 \mathrm{lb} /$ week. The food intake and economy of food utilization improved to 3.8 and $4.2 \mathrm{lb} / \mathrm{lb}$ gain, respectively. The mean intake of free nicotinic acid was $9.4 \mathrm{mg} / \mathrm{day}$, consisting of the $6 \mathrm{mg}$ from the dose and $3.4 \mathrm{mg}$ from the diet. The consumption of total nicotinic acid rose to a high value $(33.5 \mathrm{mg} /$ day $)$ owing to the large amount of bound nicotinic acid in the food and the increased intake of it; the consumption of tryptophan increased to $2 \cdot 5 \mathrm{~g} /$ day.

The four pigs in group 3 , given the tortilla diet, recovered well and gave the best performance, gaining on average $7.9 \mathrm{lb} /$ week with a food intake of $4.2 \mathrm{lb} /$ day and an economy of food utilization of $3.9 \mathrm{lb} / \mathrm{lb}$ gain. The gains in weight made by groups 2 and 3 were significantly higher than by group I (Table 9). The intake of free nicotinic acid rose in group 3 to the high value of $19.9 \mathrm{mg} /$ day, because all the nicotinic acid in the diet was in that form. The intake of tryptophan increased somewhat, though not significantly, reflecting the improved food intake (Table io).

Fig. 4 gives scatter diagrams of values for gain in weight of the individual pigs in the three groups plotted against the logarithm of the value for the intake of free or total nicotinic acid. To the former relationship a straight-line regression could be fitted $(y=-\mathrm{I} \cdot 73+8 \cdot 03 x)$. The correlation coefficient was $+0 \cdot 86$, indicating a significant relationship between the intake of free nicotinic acid and the gain in weight. For total nicotinic acid the coefficient was lower, +0.60 . The two correlation coefficients did not differ significantly $(P \sim 0 \cdot I)$.

The intake of the other vitamins ('Table II) was more than adequate, as can be seen from comparison of the values with estimated requirements (Braude, 1954; Adamstone, Krider \& James, I949).

\section{Legend for Fig. 2}

Fig. 2. Growth curves and daily intakes of food, tryptophan and nicotinic acid of individual pigs of groups $\mathrm{I}-3$. $A$, group I (deficient control pigs); $B$, group 2 (pigs given $6 \mathrm{mg}$ nicotinic acid daily); $C$, group 3 (pigs given tortilla); ....., preliminary deficiency period; - , experiment proper; $\uparrow$, beginning of experiment proper; + , died; $K$, killed. Wide columns, mean daily intake of food, tryptophan or nicotinic acid for the whole preliminary period; narrow columns, mean daily intake during experiment proper calculated for periods of I week. Top columns, intake of food (lb/day) and of tryptophan ( $\mathrm{g} /$ day); lower columns, intake of total nicotinic acid (mg/day); dark areas, free, available nicotinic acid (mg/day). 

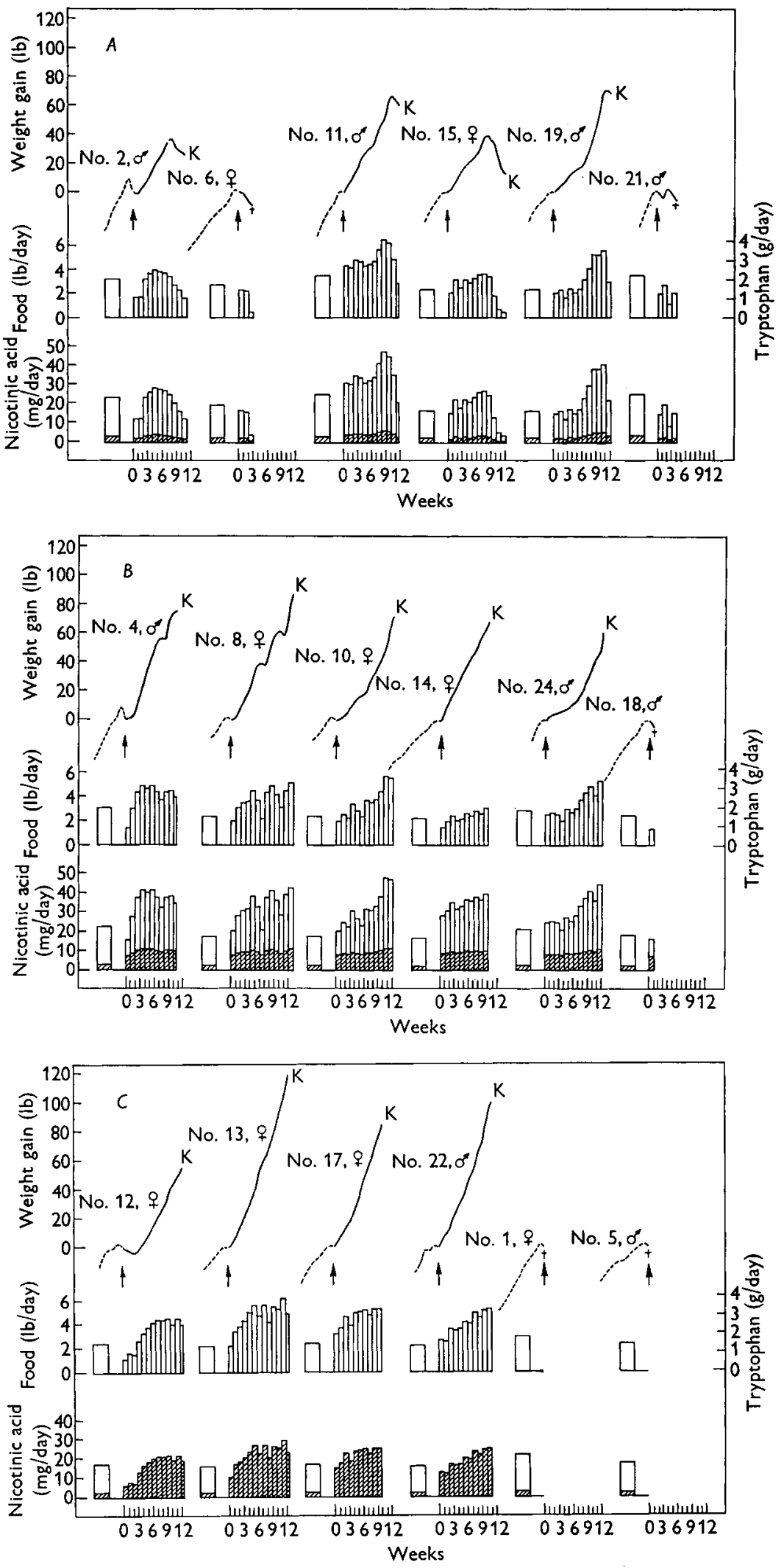

Fig. 2 (for legend see opposite page). 


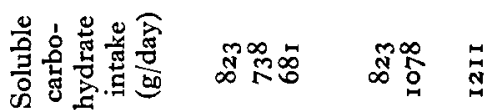

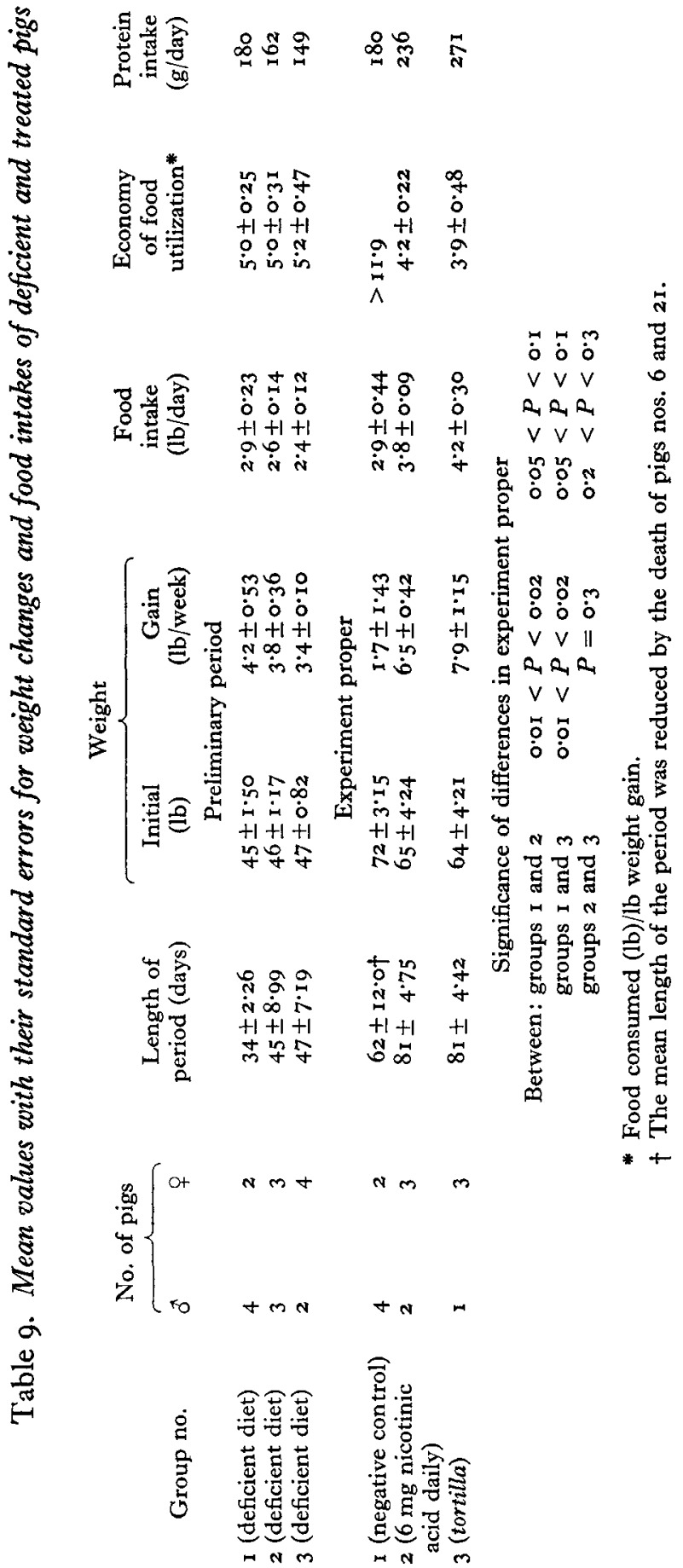


When the experiment proper ended the surviving animals were killed and their livers were analysed chemically for nicotinic acid (Table 12). The values for pigs nos. I, 5 and I 8 were included with those for the deficient control group. It will be seen that the livers contained significantly less nicotinic acid in the deficient group than in the other two groups, and in group 2, with its lower intake of free nicotinic

Table Io. Mean values with their standard errors for intakes of nicotinic acid and tryptophan of deficient and treated pigs

\begin{tabular}{|c|c|c|c|c|c|}
\hline \multirow[b]{2}{*}{ Group no. } & \multirow[b]{2}{*}{$\begin{array}{l}\text { No. of } \\
\text { pigs }\end{array}$} & \multicolumn{3}{|c|}{ Nicotinic acid (mg/day) } & \multirow[b]{2}{*}{$\begin{array}{c}\text { Tryptophan } \\
\text { (g/day) }\end{array}$} \\
\hline & & Free* & Bound & Total & \\
\hline \multicolumn{6}{|c|}{ Preliminary period } \\
\hline I (deficient diet) & 6 & $2 \cdot 6$ & $18 \cdot 4$ & $2 I \cdot 0$ & $I \cdot 9 \pm 0 \cdot I 5$ \\
\hline 2 (deficient diet) & 6 & $2 \cdot 3$ & $16 \cdot 5$ & I $8 \cdot 8$ & $1.7 \pm 0.09$ \\
\hline 3 (deficient diet) & 6 & $2 \cdot 2$ & $15 \cdot 2$ & $17 \cdot 4$ & $1.6 \pm 0.08$ \\
\hline \multicolumn{6}{|c|}{ Experiment proper } \\
\hline I (negative control) & 6 & $2.6 \pm 0.44$ & $18 \cdot 4 \pm 3 \cdot 10$ & $2 x \cdot 0 \pm 3 \cdot 10$ & $x \cdot 9 \pm 0.32$ \\
\hline $\begin{array}{l}2 \text { (6 mg nicotinic } \\
\text { acid daily) }\end{array}$ & 5 & $9 \cdot 4 \pm 0.08$ & $24 \cdot 1 \pm 0 \cdot 56$ & $33 \cdot 5 \pm 0.78$ & $2 \cdot 5 \pm 0.06$ \\
\hline $3($ tortilla $)$ & 4 & $19 \cdot 9 \pm I \cdot 43$ & $\circ$ & $19 \cdot 9 \pm 1 \cdot 43$ & $2 \cdot 8 \pm 0.20$ \\
\hline
\end{tabular}

* Derived from pea meal, maize germ and casein, and from the maize after treatment with lime-water, or from dose of nicotinic acid.

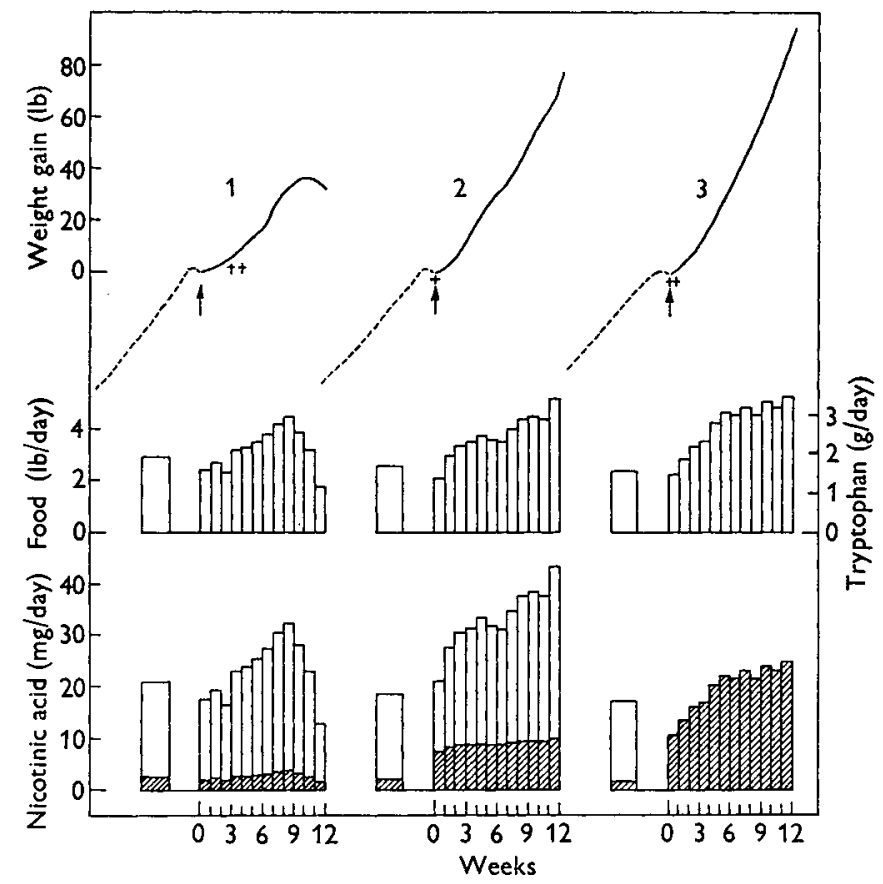

Fig. 3. Mean growth curves and daily intake of food, tryptophan and nicotinic acid of pigs deficient in nicotinic acid given various treatments for IO-I2 weeks. I, group I (deficient control pigs; two pigs died); 2, group 2 (pigs given $6 \mathrm{mg}$ nicotinic acid daily; one pig died on 8th day of experiment proper); 3 , group 3 (pigs given tortilla; two pigs died on last day of preliminary period). For explanation of symbols see Fig. 2. 
E. Kodicek, R. Braude, S. K. Kon and K. G. Mitchell $I 959$

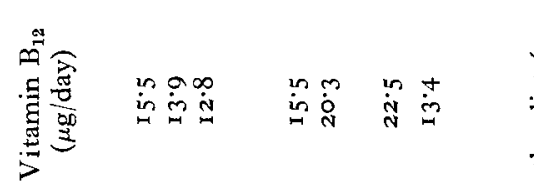

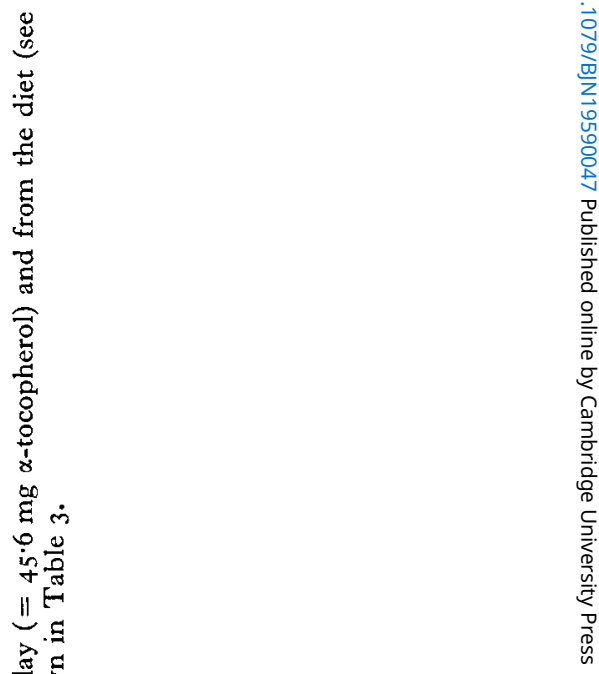

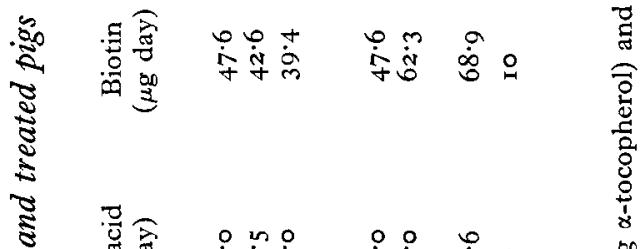

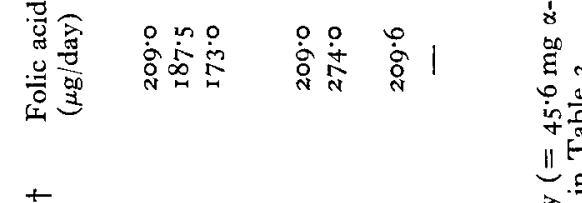

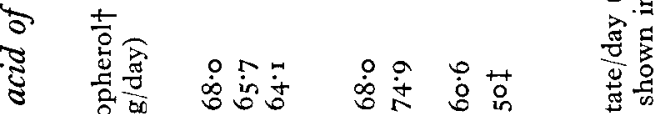

氙

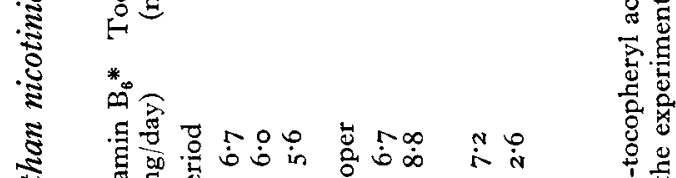

స

ذ)

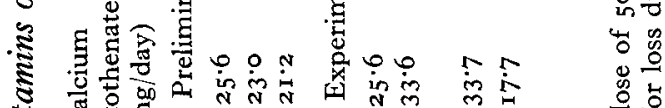

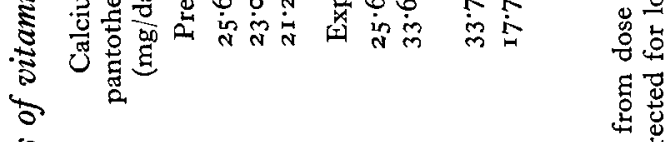

है 专蛋

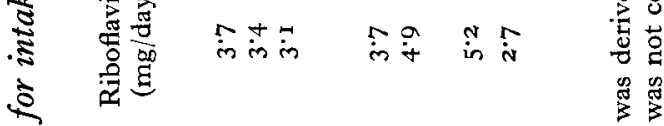

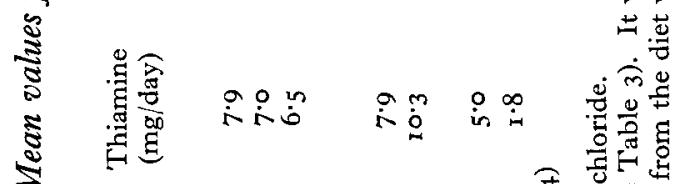

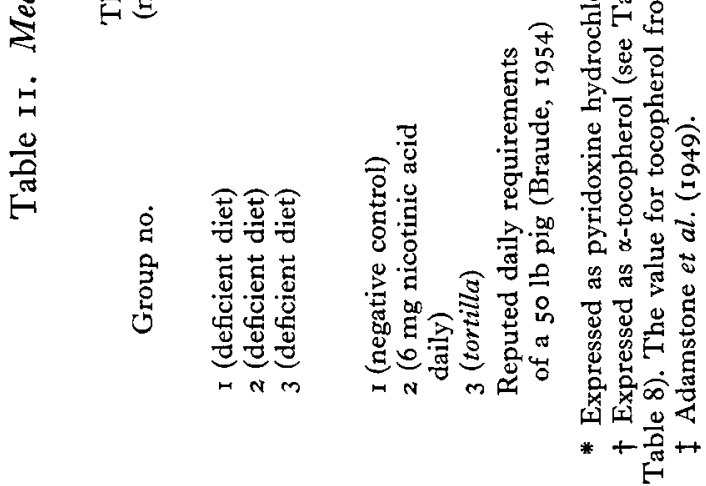


Table 12. Mean values with their standard errors for the nicotinic-acid content of liver and the tocopherol content of blood serum of deficient and treated pigs

Group no.

I (deficient diet)

$2(6 \mathrm{mg}$ nicotinic acid daily)

3 (tortilla)
Liver

nicotinic acid*

$(\mu \mathrm{g} / \mathrm{g})$

$60 \cdot 1 \pm 6 \cdot 84(9)$

$90 \cdot 1 \pm 5 \cdot 54(5)$

I09.0 I I.33（4)
Serum

tocopherol

(mg/100 ml)

$0.26 \pm 0.088$ (4)

$0.17 \pm 0.017(4)$

$0.16 \pm 0.028(4)$

Significance of differences $(t$ test):

$$
\begin{array}{r}
\text { Between groups } I \text { and } 2 \\
I \text { and } 3 \\
2 \text { and } 3
\end{array}
$$

$$
\begin{aligned}
0.01<P & <0.02 \\
P & <0.001 \\
P & =0.02
\end{aligned}
$$$$
\begin{aligned}
& 0.2<P<0.3 \\
& 0.2<P<0.3 \\
& 0.7<P<0.8
\end{aligned}
$$

Figures in parentheses are the numbers of animals.

* Values for pigs nos. I, 5 and 18 were included with those for the deficient pigs since nos. $I$ and 5 died before starting the experiment proper and no. 18 succumbed to deficiency on the 8th day of the experiment proper.

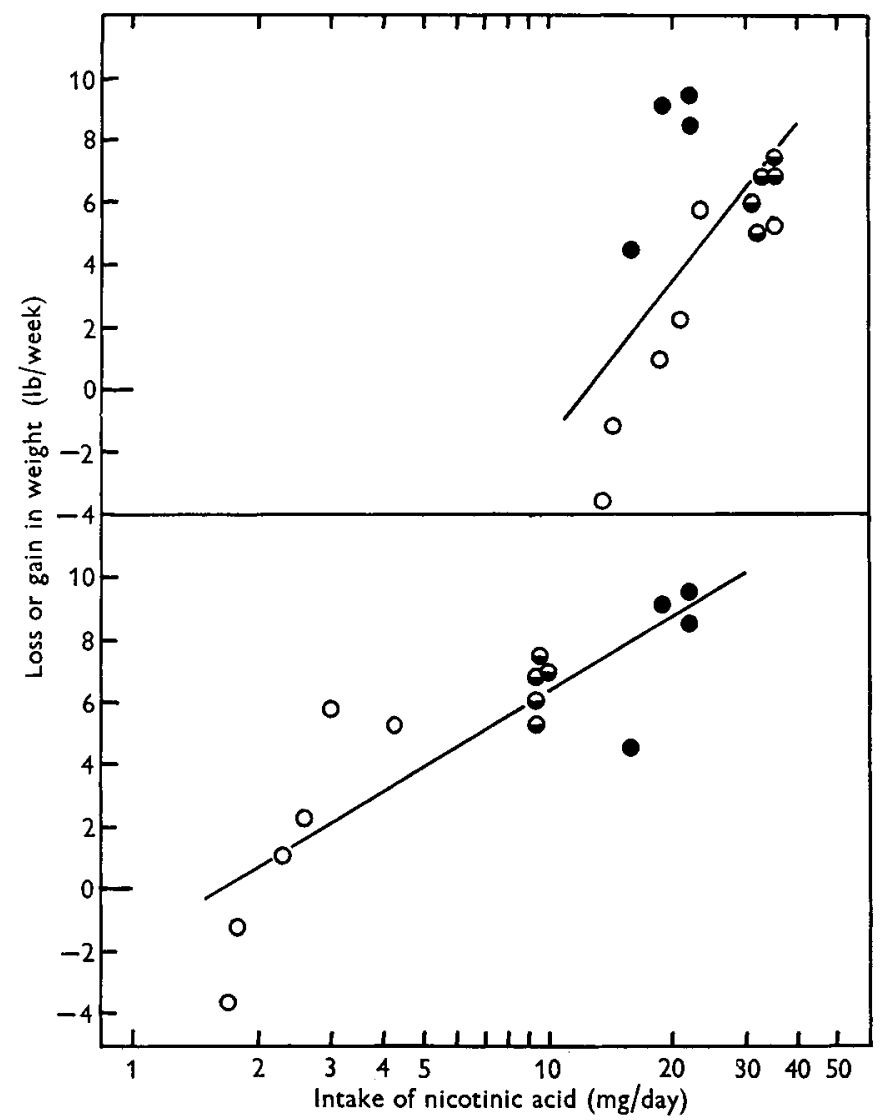

Fig. 4. Scatter diagrams showing relationship of logarithm of intake of nicotinic acid to weight change of individual pigs in the experiment proper. Upper half, intake of total nicotinic acid; lower half, intake of free, available nicotinic acid. $O$, deficient, control pigs; $\ominus$, pigs given nicotinic acid; 9 , pigs given tortilla. Straight lines, fitted regression lines. 
acid, the livers contained significantly less nicotinic acid than in group 3, given tortilla. The close correlation between the intake of free nicotinic acid and the nicotinic-acid content of the liver is evident from the scatter diagrams (Fig. 5). The regression equation was $y=40 \cdot 3 \mathrm{I}+5 \mathrm{r} \cdot 98 x$ and the correlation coefficient was $+0.8 \mathrm{I}$. Such a high degree of correlation indicates the significant relationship of the liver content to

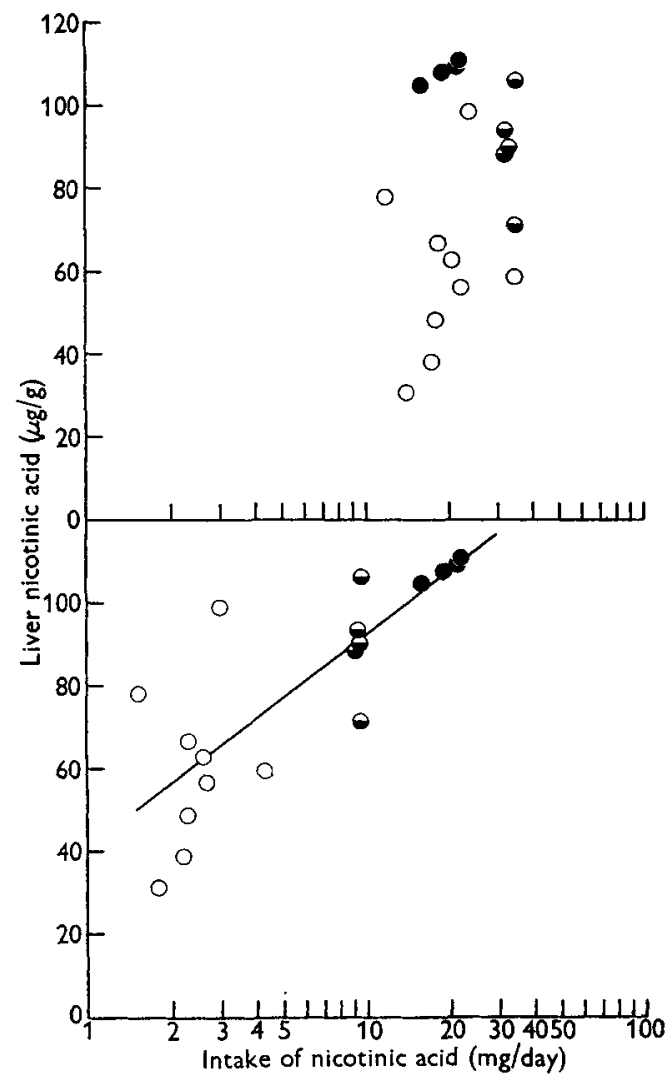

Fig. 5. Scatter diagrams showing relationship of logarithm of intake of nicotinic acid to nicotinic acid content of liver of all individual pigs (pigs nos. I, 5 and 18 included with the deficient animals). Upper half, intake of total nicotinic acid; lower half, intake of free, available nicotinic acid. For explanation of symbols see Fig. 4. Straight line, fitted regression line.

the amount of free nicotinic acid consumed. The relationship to the intake of total nicotinic acid was not significant (correlation coefficient +0.30 ) and the two correlation coefficients differed significantly $(0.02<P<0.05)$.

There was a suspicion that in the previous experiment a concurrent tocopherol deficiency might have developed in some of the pigs given alkali-treated diets (Kodicek et al. 1956), so the blood serum of the pigs was assayed for tocopherol. Table I2 shows no significant difference between the means for any of the groups, and the values were similar to those found in normal pigs (Garton, Duncan, Madsen, Shanks \& Beattie, 1958). Further, no waxy muscle degeneration or toxic liver dystrophy, 
reported to occur in tocopherol deficiency (Obel, 1953; Wanntorp \& Obel, 1957; Forbes \& Draper, 1958 ), was found in any of the pigs. It is thus evident that, despite the addition of $3 \%$ cod-liver oil to the diet and the low tocopherol content of the tortilla diet, the supplement of $350 \mathrm{mg} \alpha$-tocopheryl acetate/week prevented the occurrence of vitamin $\mathrm{E}$ deficiency.

\section{Post-mortem findings}

Mr R. M. Loosmore, B.V.Sc., M.R.C.V.S., and Mr F. W. Aston, M.R.C.V.S., of the Ministry of Agriculture, Fisheries and Food Veterinary Investigation Centre, Reading, carried out autopsies on twelve pigs, and the main conclusions were as follows:

Group I (deficient controls). Pigs nos. 2, I I, I5 and I9 were examined. All but one (no. 2) had extensive dark areas of early necrosis and ulcers in the caecum, and particularly in the colon. Pig no. 15 had large flat irregular ulcers in the oesophageal region of the stomach, necrotic typhlitis and necrotic enteritis in the colon. Ulceration in the mouth and gingivitis were found in two pigs. All those signs are in accordance with previous descriptions of nicotinic-acid deficiency (cf. Kodicek et al. 1956).

Group 2 (6 mg nicotinic acid daily). Pigs nos. 4, 8, Io and 24 were examined. They were found to be normal, except that nos. Io and 24 had a few small shallow healing ulcers in the stomach and that the mucous membrane of the caecum was oedematous and thickened.

Group 3 (tortilla). Pigs nos. I2, I3, I7 and 22 were examined. No pathological lesions were found, except that pig no. 12 had a patchy hyperaemia in the small intestine and a few small patches of early healing necrosis in the caecum.

\section{DISCUSSION}

It is evident that the supplementation with vitamins, particularly with $\alpha$-tocopheryl acetate, prevented the occurrence of other deficiencies. The intake of vitamins other than nicotinic acid was well above the reputed requirements of growing pigs. The animals thus developed nicotinic-acid deficiency without the complicating factors encountered in the previous experiment (Kodicek et al. 1956). The view is supported by the response to free nicotinic acid which induced a mean weight gain of 6.5$7.9 \mathrm{lb} /$ week, approaching that of pigs on practical diets similar in protein content to the experimental diet. Meade \& Teter (1956) obtained, with pigs given nicotinic acid, good growth, similar to that of our pigs, and satisfactory nitrogen retention on a diet with $14.2 \%$ protein, even though it was low in lysine, isoleucine and tryptophan, of which it contained $0.62,0.63$ and $0.136 \%$, respectively. Our diets were similar to that of Meade \& Teter since they contained $\mathbf{1}_{3} \cdot 8-14 \cdot 2 \%$ protein and, according to calculations based on the values of Block ( 1945 ), about $0.68 \%$ lysine, $0.82 \%$ isoleucine and $0.145 \%$ tryptophan (the last determined by chemical assay).

Paper chromatography and microbiological assay showed that in tortilla all the nicotinic acid was in available, free form, whereas in untreated maize $98.3 \%$ of it was in 
bound form. The response of deficient pigs to the tortilla diet or to a supplement of $6 \mathrm{mg}$ nicotinic acid daily was proportional to the intake of free nicotinic acid. Thus, deficient pigs were cured by $19.9 \mathrm{mg}$ free nicotinic acid which they derived daily from the tortilla diet or by $9.4 \mathrm{mg}$ daily in the free form (of which $6 \mathrm{mg}$ were contributed by dosing) from a total of $33.5 \mathrm{mg}$, but those that received only $2.6 \mathrm{mg}$ daily in the free form, from a total of $2 \mathrm{I} \mathrm{mg}$, remained deficient. A close correlation was demonstrated between the logarithm of the dose of free nicotinic acid and the weight gain. A lower correlation was found with the intake of total nicotinic acid, which included the unavailable, bound form. Further, the nicotinic-acid content of the liver was closely correlated with the intake of free, but not of total, nicotinic acid. We believe the evidence to be conclusive that the differences in performance of the pigs in the three groups were related solely to the differences in consumption of free nicotinic acid, which was supplied as a supplement or in the tortilla.

When the nutritional status of the treated pigs improved, their food consumption increased, and in proportion with it their intake of tryptophan and of the other amino acids rose. As had been expected, a good correlation was found between the logarithm of the value for food intake and the weight gain (correlation coefficient +0.94). The concentration of $0.145 \%$ tryptophan in the diet was not enough to allow for conversion of some of the amino acid into nicotinic acid, and at that concentration, in absence of available nicotinic acid, the daily intake of $\mathrm{r} \cdot 9 \mathrm{~g}$ tryptophan had no effect and the pigs remained deficient. The level of $0.145 \%$ tryptophan in our diets is somewhat lower than that of $0.19 \%$ found by Firth \& Johnson (1956) to be required for growth in presence of excess nicotinic acid. It is unlikely that in the treated pigs the greater tryptophan intake, 2.5 or $2.9 \mathrm{~g} /$ day as against $\mathrm{I} \cdot 9 \mathrm{~g}$ for the negative controls, resulted in conversion of the amino acid into the vitamin, since higher concentrations of tryptophan, about $0.45 \%$ in the diet, are required for growth when nicotinic acid is absent (Firth \& Johnson, I956), and since conversion into nicotinic acid appears to occur only when the nitrogen requirement is satisfied (Vivian, Chaloupka \& Reynolds, 1958). Further, the high correlation coefficient and the straight-line relationship between the logarithm of the dose of available nicotinic acid and the weight gain are a sign that little or no tryptophan was converted into the vitamin for, had it been so, no straight-line relationship could have been shown for a first-order equation. The same considerations apply to the close relationship between the dose of available nicotinic acid and the liver content of nicotinic acid.

The explanation that the beneficial effect of alkali-treated maize on nicotinic-acid deficiency is due to liberation of nicotinic acid from its bound form is accepted by most workers in the field (see p. $3^{63}$ ), but Bressani \& Scrimshaw (r958) expressed the view that the lime-water treatment may correct the imbalance of amino acids in maize diets by rendering the zein less digestible by enzymes, despite the fact that they, like other workers, were not able to find significant differences between the amino-acid content of maize and of tortilla. The isoleucine: leucine ratio, they suggest, may have altered in favour of isoleucine, a limiting amino acid in maize diets for growth of rats (Benton, Harper \& Elvehjem, I955). The experiments of Harper et al. (I958), however, show unequivocally that the effect on maize of alkali treatment cannot be attributed 
to the presence in excess of an individual amino acid or to an increase in the availability of amino acids that are limiting for growth. Recent reports by Scrimshaw, Bressani, Béhar \& Viteri (1958) and Bressani, Scrimshaw, Béhar \& Viteri (1958) on the amino-acid supplementation of 'corn masa' to balance the nitrogen retention of young children show that the 'corn masa' still had the properties of an unbalanced protein, capable of correction by amino-acid supplementation. Further evidence, that alkaline hydrolysis does not correct the amino-acid imbalance caused by the poor quality of zein, is supplied by the observation of Kodicek ( $195^{\mathrm{I}} b$ ) that zein treated with alkali did not cure nicotinic-acid deficiency in rats; even addition of those amino acids reported by Kligler \& Krehl (I950) to supplement the deficient protein had no beneficial effect in absence of available nicotinic acid.

The findings of Goldsmith et al. (1956), that maize treated with lime-water failed to prevent the development of human pellagra, are, by their own showing, due to the smallness of the amount of treated maize present in the diet. From the data furnished by those authors we have tentatively calculated that their maize diet supplied about $2.6 \mathrm{mg}$ free nicotinic acid out of a total of $4.8-5.2 \mathrm{mg}$, and the treated-maize diet could have supplied only $3.8 \mathrm{mg}$ free nicotinic acid out of the total of $4.9-5.4 \mathrm{mg}$ as tabulated. The excess of $\mathrm{I} \cdot 2 \mathrm{mg}$ would be liberated, free nicotinic acid, but the amount would not be enough to correct the deficiency. On the other hand, in a diet containing as much as $80 \%$ alkali-treated maize, as consumed in Central America (Goldsmith et al. I956), the amount would be similar to that in the tortilla diet used in our experiments, from which our animals obtained as much as $19.9 \mathrm{mg}$ free nicotinic acid daily.

Attempts to explain the incidence of pellagra have been complicated by the postulation that there is a toxic factor in maize (Woolley, 1946). The non-availability of bound nicotinic acid together with a low intake of tryptophan and an imbalance of amino acids can, however, explain satisfactorily the pellagra-producing effect of maize without recourse to such a hypothesis. A similar view has been expressed by Harper et al. (1958). Pearson, Valenzuela \& Van Eys (1958) recently re-investigated the possibility that there is in maize a toxic factor soluble in alkaline chloroform, but under their experimental conditions they could not detect a specific growth-inhibiting factor in either maize or zein. A low intake of tryptophan is, however, involved in the appearance of pellagra. Thus, for instance, the low incidence of pellagra in populations consuming maize and millet can be explained by the high tryptophan content of millet (Mangay, Pearson \& Darby, 1957).

The findings of Pearson et al. (1957) that the boiling of maize with water for $4 \mathrm{~h}$ releases nicotinic acid appears to militate against the importance of lime-water treatment as an efficient pellagra-preventive measure. However, we concur with Harper et al. (1958) that boiling with water for shorter periods had no effect on the release of bound nicotinic acid; even after boiling for $5 \mathrm{~h}$ only about $14 \%$ of bound nicotinic acid was liberated, an amount which had no beneficial effect on severely deficient rats (Carpenter, Kodicek \& Wilson, I960).

It appears thus that the mechanism suggested by Kodicek (1940a, b) for the pellagra-producing effect of maize goes a long way to explain the incidence of pellagra in 
certain maize-eating communities and its absence in other parts of the world, where maize is consumed after alkali treatment during which the bound nicotinic acid in the cereal is set free.

\section{SUMMARY}

I. In agreement with previous findings, it was shown by microbiological and paperchromatographic examination that maize has all or almost all its nicotinic acid in a bound form, which is unavailable to pigs as well as to other animals and is only partly available to micro-organisms. Treatment with I \% lime-water and subsequent baking of the mash, according to the method practised in Central America for the preparation of tortilla, liberated all the nicotinic acid in maize from its bound form.

2. Eighteen Large White weanling pigs were divided at random into three groups of six, each allotted to one of three treatments. All received a diet containing $79 \%$ maize until an uncomplicated nicotinic-acid deficiency was produced. Three pigs died during that period.

3. In one group the four remaining pigs were given for 10-1 2 weeks the deficient diet modified by replacing the maize by maize treated with lime-water and baked into tortilla. They recovered from the deficiency.

4. In a second group the six deficient pigs were maintained on the maize diet; they remained deficient and two of them died.

5. In a third group the five surviving deficient pigs were given the maize diet and $6 \mathrm{mg}$ nicotinic acid daily; they recovered from the deficiency.

6. A high degree of correlation was found between the logarithm of the value for the intake of free nicotinic acid and the value for the weight gain of the treated pigs.

7. A similar close relationship was established with the nicotinic-acid content of the livers. The higher the intake of free nicotinic acid, the greater was the nicotinicacid content. No such relationship was found between the intake of total nicotinic acid and liver content.

8. It is suggested that the beneficial effect of tortilla in curing the nicotinic-acid deficiency in pigs may be attributed solely to the release of nicotinic acid from an unavailable, bound form, and not to an increased intake of tryptophan or the correction or prevention of an amino-acid imbalance.

The experiments would not have been possible without the generous assistance of Huntley and Palmers Ltd, Reading, who carried out the large-scale preparation of tortilla. We are particularly grateful to Dr R. T. Colgate and Dr R. Falconer of that firm for their willing help. We are greatly indebted to Mr R. M. Loosmore, B.V.Sc., M.R.C.V.S., and Mr F. W. Aston, M.R.C.V.S., for the post-mortem examination of the pigs, to Dr M. E. Gregory for the estimation of a number of the vitamins, and to Dr R. J. Ward for the estimation of tocopherols. We are also grateful to Dr J. Green, Vitamins Ltd, for the generous gift of $\alpha$-tocopheryl acetate. We are indebted to Dr J. G. Rowell, A.R.C. Statistics Group, University of Cambridge, for valuable advice on the statistical treatment. We wish to thank $\mathrm{Mr}$ P. W. Wilson for technical assistance and much help with assays and Mr R. S. Barber for assistance with the experimental animals. 
Note added 8 May 1959. Since this paper was prepared, Squibb, Braham, Arroyave \& Scrimshaw (1959) have modified their view in that 'lime treatment of corn for the preparation of tortillas apparently increases the availability of niacin'. They suggest that 'lime treatment of corn may still be a minor contributing factor to the absence of pellagra among Central American and Mexican rural populations... but that the relatively high consumption of beans is a factor of greater significance. . . also coffee may play a role as a source of dietary niacin'. This view is in entire agreement with the thesis evolved in this communication, particularly since it has been already pointed out that legumes have their nicotinic acid in available, free form (Kodicek, I95 I $a$; Kodicek et al. 1956). The relative importance, for prevention of pellagra, of treatment of maize with lime-water and of consumption of other food constituents containing available nicotinic acid will depend on the proportions of free nicotinic acid supplied by the various foodstuffs. It would appear that a significant amount of available nicotinic acid could be supplied by tortilla, which may contribute as much as $80 \%$ of the calories of the rural diet (Anderson, Calvo, Robinson, Serrano \& Payne, I948).

\section{REFERENCES}

Adamstone, F. B., Krider, J. L. \& James, M. F. (r949). Ann. N.Y. Acad. Sci. 52, 260.

Anderson, R. K., Calvo, J., Robinson, W. D., Serrano, G. \& Payne, G. C. (1948). Amer. F. publ. Hlth, 38, i 126.

Benton, D. A., Harper, A. E. \& Elvehjem, C. A. (1955). Arch. Biochem. Biophys. 57, 13.

Block, R. J. (1945). Advanc. Protein Chem. 2, I 9.

Braude, R. (1954). In Progress in the Physiology of Farm Animals, Vol. 1, p. 40. [J. Hammond, editor.] London: Butterworth Scientific Publications.

Bressani, R., Paz y Paz, R. \& Scrimshaw, N. S. (1958). F. agric. Fd Chem. 6, 770.

Bressani, R. \& Scrimshaw, N. S. (1958). F. agric. Fd Chem. 6, 774.

Bressani, R., Scrimshaw, N. S., Béhar, M. \& Viteri, F. (1958). F. Nutr. 66, 501.

Carpenter, K. J., Kodicek, E. \& Wilson, P. (1960), Brit. F. Nutr. 14. (In the Press).

Chapman, H. R., Ford, J. E., Kon, S. K., Thompson, S. Y., Rowland, S. J., Crossley, E. L. \& Rothwell, J. (1957). F. Dairy Res. 24, 191.

Chaudhuri, D. K. \& Kodicek, E. (1950). Biochem. F. 47, xxxiv.

Clegg, K. M., Kodicek, E. \& Mistry, S. P. (1952). Biochem. F. 50, 326.

Coates, M. E., Ford, J. E., Harrison, G. F., Kon, S. K., Shepheard, E. E. \& Wilby, F. W. (1952). Brit. F. Nutr. 6, 75.

Cravioto, O. Y., Figueroa, F. de M., Cravioto, R. O. \& Massieu, G. H. (1952). Ciencia, Méx., 12, I9.

Cravioto, R. O., Anderson, R. K., Lockhart, E. E., Miranda, F. de P. \& Harris, R. S. (1945). Science, I02, $9 \mathrm{I}$.

Cravioto, R. O., Massieu, G. H., Cravioto, O. Y. \& Figueroa, F. de M. (1952). F. Nutr. 48, 453.

Fiorentini, M., Gaddi, A. M. \& Bonomolo, A. (1956). Boll. Soc. ital. Biol. sper. 32, 793.

Firth, J. \& Johnson, B. C. (1956). Э. Nutr. 59, 223.

Forbes, R. M. \& Draper, H. H. (1958). F. Nutr. 65, 535.

Garton, G. A., Duncan, W. R. H., Madsen, K. A., Shanks, P. L. \& Beattie, I. S. (1958). Brit. $\mathcal{F}$. Nutr. 12, 97.

Goldsmith, G. A. (1956). F. Amer. diet. Ass. 32, 312.

Goldsmith, G. A., Gibbens, J., Unglaub, W. G. \& Miller, O. N. (1956). Amer. F. clin. Nutr. 4, 151.

Graham, C. E., Smith, E. P., Hier, S. W. \& Klein, D. (1947). F. biol. Chem. r68, 7I r.

Green, J., Marcinkiewicz, S. \& Watt, P. R. (1955). F. Sci. Fd Agric. 6, 274.

Gregory, M. E. (1954). Brit. F. Nutr. 8, 340.

Harper, A. E., Punekar, B. D. \& Elvehjem, C. A. (1958). F. Nutr. 66, 163.

Harris, L. J. \& Wang, Y. L. (I94I). Biochem. F. 35, 1050.

Heathcote, J. G., Hinton, J. J. C. \& Shaw, B. (1952). Proc. roy. Soc. B, x39, 276.

Heuser, G. F. \& Scott, M. L. (1953). Poult. Sci. 32, r37.

Kligler, D. \& Krehl, W. A. (1950). F. Nutr. 41, 215.

Kodicek, E. (1940a). Biochem. F. 34, 712 .

Kodicek, E. (1940b). Biochem. F. 34, 724. 
Kodicek, E. (1942). Biochemical studies on nicotinic acid. Ph.D. Thesis, University of Cambridge.

Kodicek, E. (195Ia). Rep. Progr. Chem. 48, 276.

Kodicek, E. (195I $b$ ). Biochem. F. 48, viii.

Kodicek, E., Braude, R., Kon, S. K. \& Mitchell, K. G. (1956). Brit. F. Nutr. ro, 5 I.

Kodicek, E. \& Pepper, C. R. (1948). F. gen. Microbiol. 2, 306.

Kodicek, E. \& Wang, Y. L. (1949). Biochem. F. 44, 340.

Kodicek, E. \& Wilson, P. W. (1959). Brit. F. Nutr. 13. (In the Press.)

Krehl, W. A., Elvehjem, C. A. \& Strong, F. M. (1944). F. biol. Chem. 156, 13.

Krehl, W. A., Henderson, L. M., de la Huerga, J. \& Elvehjem, C. A. (1946). F. biol. Chem. I66, 531.

Krehl, W. A. \& Strong, F. M. (1944). F. biol. Chem. I56, I.

Laguna, J. \& Carpenter, K. J. (I95 I). F. Nutr. 45, 2 I.

McDaniel, E. G. \& Hundley, J. M. (1958). Fed. Proc. 17, 484.

Mangay, A. S., Pearson, W. N. \& Darby, W. J. (1957). F. Nutr. 62, 377.

Massieu, G. H., Cravioto, O. Y., Cravioto, R. O., Guzmán, J. \& Suarez Soto, G. Y. M. de L. (1956). Ciencia, Méx., 16, 24.

Massieu, G. H., Guzmán, J., Cravioto, R. O. \& Calvo, J. (1949). F. Nutr. 38, 293.

Meade, R. J. \& Teter, W. S. (I956). F. Nutr. 6o, 609.

Moore, T., Sharman, I. M. \& Ward, R. J. (1959). Brit. F. Nutr. 13, 100.

Neilands, J. B. \& Strong, F. M. (1948). Arch. Biochem. 19, 287.

Obel, A.-L. (1953). Acta path. microbiol. scand. Suppl. 94.

Paz y Paz, R. (1953). Esc. farm., Guatemala, 14, 2.

Pearson, W. N., Stempfel, S. J., Valenzuela, J. S., Utley, M. H. \& Darby, W. J. (1957). F. Nutr. 6z, 445 .

Pearson, W. N., Valenzuela, J. S. \& van Eys, J. (1958). F. Nutr. 66, 277.

Pellett, P. L. \& Platt, B. S. (1956). Nature, Lond., 177, 422.

Quaife, M. L. \& Harris, P. L. (1944). F. biol. Chem. 156, 499.

Sarett, H. P. \& Cheldelin, V. H. (1944). F. biol. Chem. 155, 153.

Sauberlich, H. E. \& Baumann, C. A. (1948). F. biol. Chem. 176, 165.

Scrimshaw, N. S., Bressani, R., Béhar, M. \& Viteri, F. (1958). \%. Nutr. 66, 485.

Skeggs, H. R., Nepple, H. M., Valentik, K. A., Huff, J. W. \& Wright, L. D. (1950). F. biol. Chem. 184, 2 I I.

Squibb, R. L., Braham, J. E., Arroyave, G. \& Scrimshaw, N. S. (1955). Fed. Proc. 14, 32.

Squibb, R. L., Braham, J. E., Arroyave, G. \& Scrimshaw, N. S. (1959). F. Nutr. 67, 35 r.

Sreenivasan, A., Harper, A. E. \& Elvehjem, C. A. (1949). F. biol. Chem. 177, I I7.

Teply, L. J. \& Elvehjem, C. A. (1945). F. biol. Chem. r57, $3 \circ 3$.

Vivian, V. M., Chaloupka, M. M. \& Reynolds, M. S. (1958). F. Nutr. 66, 587.

Wang, Y. L. \& Kodicek, E. (1943). Biochem. F. 37, 530.

Wanntorp, H. \& Obel, A.-L. (1957). Acta chem. scand. I1, 1418.

Ward, R. J. (1958). Some aspects of the estimation, biological potency and antioxidant activity of the tocopherols. Ph.D. Thesis, University of Cambridge.

Woolley, D. W. (1946). F. biol. Chem. 163, 773 . 